\title{
Hieracium lanceolatum (Asteraceae) does not occur in Britain
}

\author{
Timothy C.G. Rich \\ Cardiff, U.K.
}

Corresponding author: Timothy C.G. Rich: tim rich@sky.com

This pdf constitutes the Version of Record published on $30^{\text {th }}$ June 2020

\begin{abstract}
The status of Hieracium lanceolatum Vill. in Britain has been reviewed against the original descriptions and material from the western Alps. British plants named as $H$. lanceolatum show a poor match with $H$. lanceolatum and fit $H$. prenanthoides Vill. better. It is concluded that $H$. lanceolatum does not occur in Britain.
\end{abstract}

Keywords: Hieracium section Prenanthoidea; Hieracium prenanthoides

\section{Introduction}

Hieracium prenanthoides Vill. and $H$. lanceolatum Vill. (Hieracium section Prenanthoidea W. D. J. Koch) were both described from Dauphiné, France in the western Alps by Domínique Villars. Hieracium prenanthoides was briefly described as having an erect stem, a conical, finely branched inflorescence, and elliptic, hairy leaves with amplexicaul bases (Villars, 1779). In its broad sense, H. prenanthoides has been recorded from Greenland, Iceland and Scandinavia to central Europe as far as western Asia and Siberia (cf. Pugsley, 1948, Sell \& West, 1976; Tyler, 2010; Gottschlich \& Raabe, 2011; Chrtek et al. 2020). A range of ploidy levels occur; diploids $(2 n=18)$ occur in the SW Alps in France and Italy (but not elsewhere), triploids $(2 n=27)$ are widespread in Europe and the Carpathians, and tetraploids $(2 n=36)$ have been recorded from Central Europe and Iceland (Chrtek et al., 2004, 2007, 2020; Ilnicki \& Szeląg, 2011; Kocián, 2013).

Hieracium lanceolatum was described as having erect, rigid stems, lanceolate, toothed leaves and a subcorymbose inflorescence, and was illustrated in Tab. 30 (Villars, 1788). Villars also contrasted his new $H$. lanceolatum with $H$. prenanthoides and $H$. sabaudum $L$. noting that $H$. lanceolatum had a straight, rigid stem 1-2 feet high, had all leaves on the stem semi-amplexicaul, had numerous, elliptic-lanceolate, hairy, pale leaves which were toothed on the margins, with an inflorescence of 1012 flowers with a small black 'calyx' (i.e. involucral bracts). Villars' description is not particularly helpful in separating $H$. lanceolatum from all the other hawkweeds known today, and consequently it has been interpreted in slightly different ways in Europe (e.g. Arvet-Touvet 1873; Zahn, 1922; Tison \& de Foucault, 2014). In its broad sense, $\mathrm{H}$. lanceolatum has been recorded as widespread in the mountains of central Europe in Austria, Czech Republic, France, Germany, Poland, Romania, Spain, Switzerland and the former Yugoslavia (Sell \& West, 1976). The only chromosome count traced is triploid ( $2 n=27)$ from Slovakia (Májovský, 1974); the 
triploid count from Turkey (Hayirlioğlu-Ayaz \& İnceer, 2004) does not clearly belonging to the same taxon.

Zahn (1922) in his monograph of European Hieracium included both taxa under his Species Principalia Collectiva $H$. prenanthoides Vill. in different groups, $H$. prenanthoides in grex $H$. prenanthoides (Vill.) Zahn with 30 other subspecies and $H$. lanceolatum in grex $H$. lanceolatum (Vill.) Zahn with 20 other subspecies, the latter grex differing in having narrower, lanceolate leaves 3-6 times as long as wide.

Hieracium prenanthoides and $H$. lanceolatum have also been variably treated in British Hieracium accounts. Some British authors cite both $H$. prenanthoides and $H$. lanceolatum as present in Scotland and some authors cite only $H$. prenanthoides. It is undisputed that $H$. prenanthoides in its broad sense is widespread in northern and western Britain, with one record for Ireland (McCosh \& Rich, 2018).

Williams (1902) cited the "first certain and definite" record for $\mathrm{H}$. lanceolatum as the plants described as H. strictum Fr. by Hooker \& Arnott (1850). However, it is not clear which species Hooker \& Arnott were actually referring to from their description, and the name $H$. strictum has been applied to several species in Hieracium section Foliosa but none in section Prenanthoidea. Williams (1902) included both $H$. prenanthoides and $H$. lanceolatum in his account and augmented Villars' original description of $H$. lanceolatum with the addition of pilose hairs on the bracts, and he cited specimens from E. F. and W. R. Linton's Set of British Hieracia no. 73 from Inverey, Braemar, Aberdeenshire, which are clearly $H$. strictiforme (Zahn) Roffey in section Foliosa; Williams' treatment of $H$. lanceolatum is therefore rejected. According to Sell (1987), William's work has generally been ignored as he did not possess any intrinsic knowledge of Hieracium, though Pugsley (1948) is a little more circumspect.

Backhouse (1856) and Linton (1905) only included H. prenanthoides in their monographs of British Hieracium.

Zahn (1922) cited material of $H$. lanceolatum (as $H$. prenanthoides subsp. lanceolatum (Vill.) Zahn) from Braemar and material of $H$. prenanthoides subsp. strictissimum (Froel.) Zahn from Fortingall, Perthshire and Braemar, but did not cite any British material under $H$. prenanthoides subsp. prenanthoides. Unfortunately, as the collections on which Zahn's work was based on were destroyed in Berlin during the Second World War (Stafleu \& Cowan, 1988), it is not possible to examine the British specimens that Zahn saw.

Pugsley (1948) only accepted $H$. prenanthoides Vill. for Britain, and, noting Zahn's records, stated "the varying examples of this group occurring in these stations are shown (in herbarium specimens) by their pale achenes to be forms of $H$. prenanthoides".

Most recently, Sell \& Murrell (2006) accepted $H$. lanceolatum for Britain stating "A series of specimens collected from the banks of the River Clunie at Braemar in Aberdeenshire seem to fit this species which differs from $H$. prenanthoides by its more rigid habit, numerous simple eglandular hairs in the inflorescence and almost black, broader involucral bracts. However, typical $H$. prenanthoides also grows at the same locality and the situation needs examining in the field". Sell \& Murrell (2006) also regarded Zahn's Braemar record for $H$. prenanthoides subsp. strictissimum as $H$. lanceolatum, but noted the only specimens seen from Fortingall were typical $H$. prenanthoides. 
Field work by T. Rich at the River Clunie, Braemar in 2016 showed that the plants at Braemar had relatively broad, dark involucral bracts but there was much variation in the quantity of simple hairs in the inflorescences and that further studies were needed (McCosh \& Rich, 2018). The status of H. lanceolatum in Britain has now been examined in more detail, drawing on the original descriptions and material, with an analysis of herbarium material, examination of additional populations in Scotland and cultivation of two populations from seed.

Characters separating $H$. prenanthoides and $H$. lanceolatum from Villars (1779; 1788) and Zahn (1922) are summarised in Table 1 and from Sell \& Murrell (2006) in Table 2. These emphasise the different characters used in Europe and Britain, the key differences being use of leaf shape and toothing in Europe and use of simple hairs on the peduncles and bracts in Britain.

Table 1. Characters separating $H$. prenanthoides and $\boldsymbol{H}$. lanceolatum in Europe (Villars 1779, 1788; Zahn 1922).

\begin{tabular}{|c|c|c|}
\hline Character & Hieracium prenanthoides & Hieracium lanceolatum \\
\hline Stem & $90-120 \mathrm{~cm}$ & Stout, rigid, 30-60 cm high \\
\hline $\begin{array}{l}\text { Number of stem } \\
\text { leaves }\end{array}$ & Up to 40 & $15-25(-40)$ \\
\hline Leaf shape & Ovate to oblong-lanceolate & $\begin{array}{l}\text { Elliptic or lanceolate 3-6 } \\
\text { times as long as wide }\end{array}$ \\
\hline Leaf margins & $\begin{array}{l}\text { Subentire to remotely } \\
\text { denticulate }\end{array}$ & Denticulate to serrate \\
\hline Leaf base & Amplexicaul & Attenuate, semi-amplexicaul \\
\hline Involucre length & $(7-) 8-9 \mathrm{~mm}$ & $9-12 \mathrm{~mm}$ \\
\hline Achenes & Grey or yellow-brown & $\begin{array}{l}\text { Reddish-brown or dark } \\
\text { brown, rarely yellowish- } \\
\text { brown }\end{array}$ \\
\hline
\end{tabular}

\section{Methods}

Original material

Images of Villars herbarium at Muséum d'Histoire Naturelle de Grenoble (GRM) were provided by M. Lefebvre (pers. comm. 2019). Images are available on the GRM website.

\section{Comparative morphology}

Characters were examined on 95 specimens in BM, CGE, E and NMW, comprising $60 \mathrm{H}$. prenanthoides and $35 \mathrm{H}$. lanceolatum specimens of which 54 were from Britain and 41 from Europe. The numbers of specimens of each group examined was primarily determined by the availability of good specimens, and very little material of $H$. lanceolatum was available from Britain where it is rare. 
Table 2. Characters separating $H$. prenanthoides and $H$. lanceolatum in Britain (Sell \& Murrell 2006).

\begin{tabular}{|l|l|l|}
\hline Character & Hieracium prenanthoides & Hieracium lanceolatum \\
\hline Stem & $40-100 \mathrm{~cm}$ & $40-70 \mathrm{~cm}$ \\
\hline $\begin{array}{l}\text { Number of stem } \\
\text { leaves }\end{array}$ & $12-30$ & (Not stated) \\
\hline Upper leaf shape & $\begin{array}{l}\text { Lanceolate, narrowly } \\
\text { elliptical, oblong-lanceolate } \\
\text { and ovate }\end{array}$ & $\begin{array}{l}\text { Lanceolate, ovate or } \\
\text { elliptical }\end{array}$ \\
\hline Leaf margins & $\begin{array}{l}\text { Entire to denticulate, } \\
\text { sometimes with a few large } \\
\text { teeth }\end{array}$ & $\begin{array}{l}\text { Entire to remotely } \\
\text { denticulate }\end{array}$ \\
\hline Leaf base & Cordate-semiamplexicaul & Auriculate-amplexicaul \\
\hline $\begin{array}{l}\text { Simple hairs on } \\
\text { peduncles }\end{array}$ & $\begin{array}{l}\text { Sometimes an occasional } \\
\text { simple hair }\end{array}$ & Numerous \\
\hline Involucre length & 3-10 mm & 3-10 mm \\
\hline Involucral bract width & $0.8-1.3$ & $1.0-1.5 \mathrm{~mm}$ \\
\hline $\begin{array}{l}\text { Involucral bract } \\
\text { colour }\end{array}$ & Dark olive green & Blackish \\
\hline $\begin{array}{l}\text { Simple hairs on } \\
\text { involucral bracts }\end{array}$ & $\begin{array}{l}\text { Sometimes an occasional } \\
\text { simple hair }\end{array}$ & Few to numerous \\
\hline
\end{tabular}

It was evident from examination of herbarium material that the stem height was very variable and the poor pressing of many specimens meant that leaf shape was too hard to quantify consistently, so the following characters were selected from the characters from Tabs. 1 and 2 and scored:

1. Number of stem leaves including withered leaves or leaf scars at the base of the stem and bracts in the synflorescences. Specimens were selected as far as possible as those with a complete stem; where lower stems were missing the number of leaves was excluded from some analyses.

2. Toothing of middle stem leaves ( $0=$ entire, $1=$ denticulate, 2 serrate).

3. Length of middle stem leaf auricle as a measure of how clasping the stem leaves were (measured as length from the node, though this was not easy to assess on some pressed leaves).

4. Presence of simple hairs on peduncles on a quantitative five-point scale $(0=a b s e n t$, 1 = rare, 2 = occasional, 3 = frequent, 4 = numerous).

5. Length of involucral bracts ( $\mathrm{mm}$, measured from base of the capitulum to tip of longest bracts; cf. Sell \& Murrell 2006).

6. Average width of three broadest bracts $(\mathrm{mm})$ using a micrometre eyepiece with 0.1 $\mathrm{mm}$ intervals.

7. Presence of simple hairs on bracts on a quantitative five-point scale $(0=a b s e n t, 1=$ rare, $2=$ occasional, 3 = frequent, $4=$ numerous).

The data were analysed in Excel, though the analysis was somewhat unsatisfactory due to the small sample sizes of British $\mathrm{H}$. lanceolatum and European $\mathrm{H}$. 
prenanthoides. Principal Components Analyses (PCA) were carried out using PAST3 (Hammer et al. 2001)

Field surveys

Field work in August 2016 and August 2019 was targeted on Fortingall, Inverey and Braemar where $H$. lanceolatum had been reported. The Dess locality was not visited. Fresh plants at these three sites were compared with fresh $H$. prenanthoides at five sites elsewhere.

\section{Cultivation}

Plants of $H$. lanceolatum from Braemar with simple hairs on the peduncles and bracts and $H$. prenanthoides from Tarren-yr-Esgob (v.c.42) without simple hairs were grown from seed side by side in a garden in Cardiff 2016-2019.

\section{Results}

\section{Original material}

Villars' herbarium is housed at Muséum d'Histoire Naturelle de Grenoble (GRM) and contains original material of both $H$. prenanthoides and $H$. lanceolatum (pers. comm., M. Lefebvre 2019). As there is only one sheet of each species labelled in Villars' handwriting, these can be regarded as holotypes.

The one sheet of $H$. prenanthoides (ref. MHNGr.1837.27515) has a small lefthand label "Hieracium prenanthoides V./ Lans [=Lans en Vercors]". The sheet has three specimens showing the numerous stem leaves (one specimen has up to 24 stem leaves and is up to $60 \mathrm{~cm}$ tall) with strongly auricled, clasping bases, and branched inflorescences, and only glandular hairs on the peduncles. A visual comparison of British $\mathrm{H}$. prenanthoides specimens gives a reasonable match against Villars' material.

The one sheet of $H$. lanceolatum (MHNGr.1837.27531) has two specimens; the left-hand specimen, composed of a lower stem part and an upper stem part, has a label "Barcelonette Hierac. lanceolatum". The specimen is somewhat damaged and has lost all the capitula but is about $60 \mathrm{~cm}$ tall with an estimated 15 stem leaves which are weakly serrate, oblong-lanceolate and have small auricles, and there are mixed frequent simple and abundant glandular hairs on the few remaining peduncles. The right-hand specimen is from Auguste Mutel's herbarium replacing a plant from Villars' herbarium and is H. umbellatum L. (redetermined by P. Mraz in 2001); it is not original material.

A comparison of British $H$. lanceolatum with Villars' original $H$. lanceolatum material is less clear due to the damaged original specimen. The Braemar plants named as H. lanceolatum (by P. D. Sell in CGE or by D. McCosh in BM) have ellipticoblong to elliptic-lanceolate leaves which are denticulate (rarely serrate) and strongly clasping at the base with involucres mostly 8-9 mm long and thus show a poor match with the original descriptions and material other than in having many simple hairs in the inflorescence, and they have mid-brown seeds rather than grey seeds (grey seeds may be present in immature fruiting heads). The Braemar plants are a good match for the detailed description of $H$. lanceolatum by Sell \& Murrell (2006) as expected as the description is largely based on that material. 
Comparative morphology

The morphological data are summarised in Table 3.

Table 3. Summary of characters of herbarium material of $\boldsymbol{H}$. prenanthoides and $\boldsymbol{H}$. lanceolatum. The data are averages with ranges.

\begin{tabular}{|c|c|c|c|c|}
\hline Character & $\begin{array}{l}\text { H. } \\
\text { prenanthoides } \\
\text { Europe } \\
(n=10)\end{array}$ & $\begin{array}{l}\text { H. } \\
\text { prenanthoides } \\
\text { Britain } \\
(\mathrm{n}=50)\end{array}$ & $\begin{array}{l}\text { H. } \\
\text { lanceolatum } \\
\text { Europe } \\
(\mathrm{n}=31)\end{array}$ & $\begin{array}{l}\text { H. } \\
\text { lanceolatum } \\
\text { Britain } \\
(n=4)\end{array}$ \\
\hline $\begin{array}{l}\text { 1. } \begin{array}{l}\text { No. stem } \\
\text { leaves }\end{array} \\
\end{array}$ & 13.3 (range 5-24) & $\begin{array}{l}19.8 \text { (range 10- } \\
30 \text { ) }\end{array}$ & $\begin{array}{l}16.7 \text { (range 9- } \\
27 \text { ) }\end{array}$ & $\begin{array}{l}17.3 \text { (range 14- } \\
23 \text { ) }\end{array}$ \\
\hline $\begin{array}{l}\text { 2. Length } \\
\text { auricle } \\
(\mathrm{mm})\end{array}$ & 2.2 (range $0-6$ ) & 2.8 (range $1-6$ ) & 1.8 (range $0-5$ ) & 3.3 (range 3-4) \\
\hline $\begin{array}{l}\text { 3. Leaf } \\
\text { toothing }\end{array}$ & 1.1 (range $1-2$ ) & 1 (range 1 ) & 1.2 (range $1-2$ ) & 1.3 (range $1-2$ ) \\
\hline $\begin{array}{l}\text { 4. Simple hairs } \\
\text { on } \\
\text { peduncles }\end{array}$ & 0.9 (range $0-3$ ) & 1.9 (range $0-4$ ) & 1.7 (range $0-4$ ) & 3 (range 3) \\
\hline $\begin{array}{ll}\text { 5. } & \text { Involucral } \\
\text { length }(\mathrm{mm})\end{array}$ & 9.7 (range 9-11) & 9.3 (range 8-11) & $\begin{array}{l}9.4 \text { (range 8- } \\
11 \text { ) }\end{array}$ & 8.8 (range 8-9) \\
\hline $\begin{array}{l}\text { 6. Involucral } \\
\text { bract width } \\
(\mathrm{mm})\end{array}$ & $\begin{array}{l}1.3 \text { (range 1.2- } \\
1.5 \text { ) }\end{array}$ & $\begin{array}{l}1.2 \text { (range } 0.8- \\
1.5 \text { ) }\end{array}$ & $\begin{array}{l}1.2 \text { (range 0.9- } \\
1.5 \text { ) }\end{array}$ & $\begin{array}{l}1.5 \text { (range 1.3- } \\
1.6 \text { ) }\end{array}$ \\
\hline $\begin{array}{l}\text { 7. Simple hairs } \\
\text { on } \\
\text { involucral } \\
\text { bracts }\end{array}$ & 0.7 (range $0-3$ ) & 1.6 (range 0-4) & 2.1 (range $0-4$ ) & 3 (range 3) \\
\hline
\end{tabular}

The number of stem leaves is variable within each group and overlaps completely. In Europe the leaf bases have slightly less clasping auricles in $H$. lanceolatum than in $H$. prenanthoides but the differences are not significant ( $T$ test, $\mathrm{p}=0.56$ ) and overall the auricles are on average about a millimetre longer in all British material than all European material ( $T$ test, $p=0.0026)$.

The leaf toothing was variable and hard to quantify objectively, but European material of $H$. lanceolatum was often more noticeably toothed than European $H$. prenanthoides and certainly than any British material of either species ( $T$ test, $\mathrm{p}=0.01$ ). The Braemar material of $H$. lanceolatum was only weakly toothed.

In $H$. lanceolatum there were generally more specimens with at least some simple hairs on the peduncles $(24 / 31=77 \%)$ than in $H$. prenanthoides $(4 / 11=36 \%)$ but overall there is no difference between in the overall amount of hairs on European material alone ( $T$ test, $p=0.10$ ) or all material ( $T$ test, $p=0.78$ ).

Involucre length shows complete overlap with no significant differences between European material alone ( $T$ test, $p=0.28$ ) or all material $(T$ test, $p=0.56)$ and the measurements for European material exceed the ranges for both species (cf. Table 1).

Involucral bract width shows no difference for European material alone ( $T$ test, $p=0.27$ ) but is different when all material is included ( $T$ test, $p=0.009)$ as all British 
material compared with all European material of both species is significantly wider ( $T$ test, $\mathrm{p}=0.02$ ).

In $H$. lanceolatum there were more specimens with more simple hairs on the bracts than in $H$. prenanthoides in European material alone ( $T$ test, $\mathrm{p}=0.002)$ and for all material ( $T$ test, $\mathrm{p}=0.004)$. However, one of the surprises in the analysis of herbarium material was the number of specimens of British $\mathrm{H}$. prenanthoides with at least some simple hairs on the peduncles $(84 \%)$ or bracts $(80 \%)$, or more hairy ones with frequent to numerous simple hairs on the peduncles (45\%) and bracts $(20 \%)$. The quantity of simple hairs on the peduncles is highly correlated with the quantity of simple hairs on the bracts $(r=0.02 ; p<0.001)$. Specimens with at least frequent to numerous hairs were widespread throughout the range of $H$. prenanthoides in Britain including Craig Cerrig-gleisiad (v.c.42), Hawes (v.c.64), Ettrick Bridge (v.c.79), Rose Cleuch (v.c.83), Glen Buckie (v.c.87), Allt Breaclaich, Glen Lochay, Glen Lyon, Killin and Strathfillan (v.c.88), Kindrogan and River Garry (v.c.89), Auchallater, Braemar and River Clunie, Inverey and Potarch Bridge (v.c.92).

For all British material of $H$. prenanthoides and $H$. lanceolatum, there was no correlation between the bract width and quantity of simple hairs on the peduncles $(r=0.02 ; p>0.1)$ or on the bracts $(r=0.09 ; p>0.1)$, showing no relationship between the character combination used in the key of Sell \& Murrell (2006).

A multivariate Principal Components Analysis (PCA) was carried out on all data to see if any overall patterns could be discerned in the data. An initial analysis of all data showed Component 1 was dominated by the number of stem leaves which accounted for $84 \%$ of the variation resulting in complete overlap amongst all group. As this character was also rejected as useful from data in Table 3, it was dropped from subsequent analyses. When only European material was analysed using the remaining six characters (Fig. 1 ), $H$. prenanthoides and $H$. lanceolatum were weakly separated with all characters except auricle length contributing to Component 1 $(30 \%)$ and involucre length and the amount of simple hairs on the bracts and peduncles contributing to Component $2(22 \%)$.

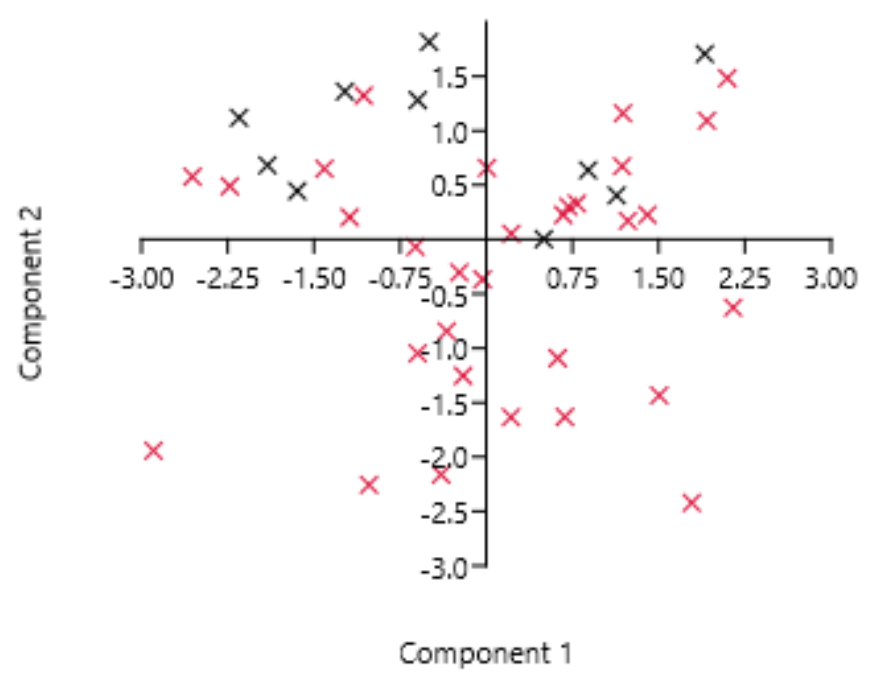

Figure 1. PCA of European $H$. prenanthoides (x) and European $\boldsymbol{H}$. lanceolatum (x) using characters 2-6 from Table 3. 
When all material was analysed (Fig. 2), there is overlap between all of the groups, the amount of simple hairs on the bracts and peduncles contributing to Component $1(47 \%)$ and bract width to Component 2 (22\%).

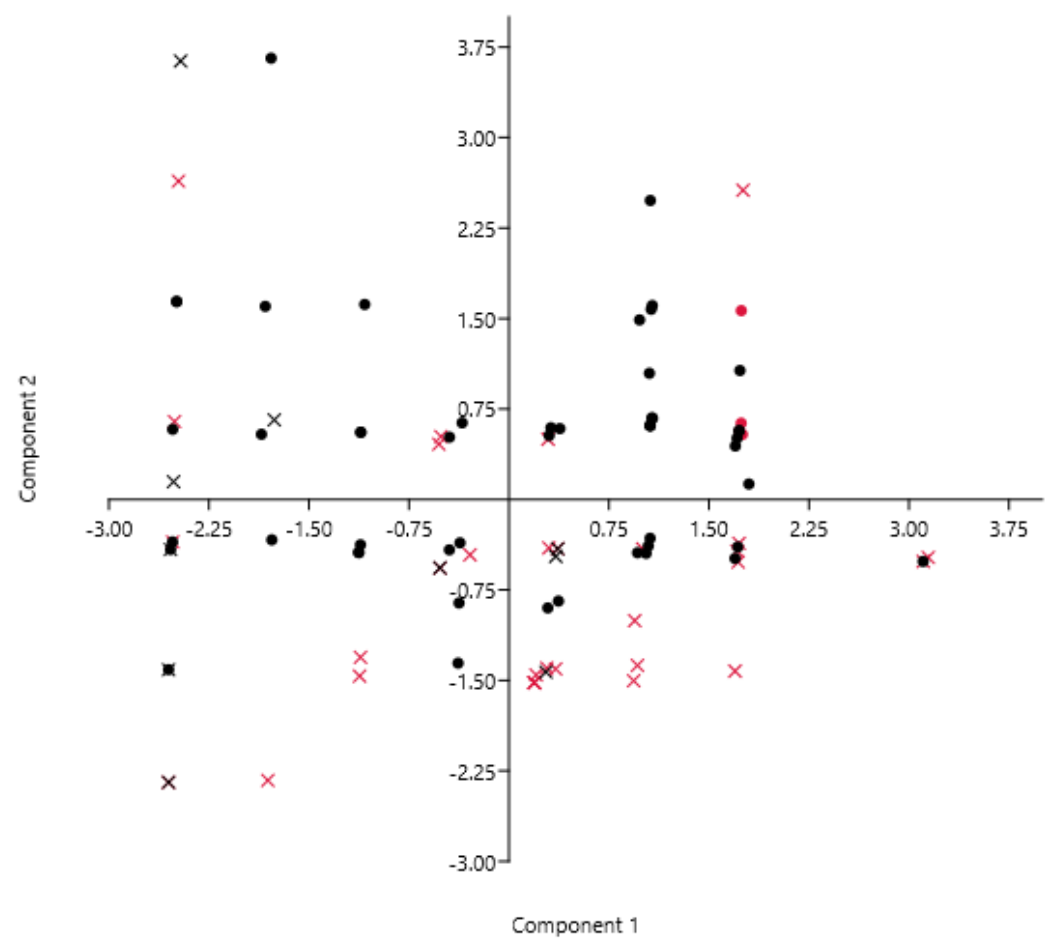

Figure 2. PCA of European $H$. prenanthoides $(x)$, British $H$. prenanthoides $(\bullet)$, European $\boldsymbol{H}$. lanceolatum $(x)$ and British $H$. lanceolatum $(\bullet)$ using characters 2-6 from Table 3.

Field surveys

Plants at the three sites where $H$. lanceolatum had been reported were compared with $H$. prenanthoides from elsewhere; other than the plants having many simple hairs on the peduncles and bracts the plants otherwise matched $H$. prenanthoides. Bract colour in both ranged from dark green in more shaded conditions to blackish in the open. The seeds, where ripe, were all pale chestnut brown.

\section{Cultivation}

Both collections in cultivation grown from seed retained the hairs characters on the peduncles and bracts that they had shown in the wild.

\section{Discussion}

Examination of the European material indicates $\mathrm{H}$. prenanthoides and $\mathrm{H}$. lanceolatum are different if variable taxa, differing in degree of toothing, leaf shape and development of auricles, but the small samples do not show significant differences in involucre length. The European material of $\mathrm{H}$. prenanthoides and $\mathrm{H}$. lanceolatum seen in herbaria is quite varied and, in both cases, may be better treated at the group levels of Zahn (1922) rather than his more closely circumscribed subspecies. A revision of this section across Europe would be beneficial but is unlikely to change the conclusions for $\mathrm{H}$. lanceolatum in Britain in this paper. 
With the exception of having many simple hairs in the inflorescence and achene colour, the Braemar plants named as $H$. lanceolatum were a poor match with the original descriptions and material of $H$. lanceolatum and fit $H$. prenanthoides better. The simple hairs in the inflorescence character was not cited by either Villars (1788) or Zahn (1922) to separate $H$. lanceolatum from $H$. prenanthoides though simple hairs are present in the inflorescence present in the original material of $H$. lanceolatum. The presence of simple hairs in the inflorescence was used by Sell \& Murrell (2006) to characterise $H$. lanceolatum and appears to be unique to the British interpretation. Plants with simple hairs in the inflorescence are scattered throughout the range of $\mathrm{H}$. prenanthoides in Britain and also occur in Europe, and the occurrence of simple hairs in the inflorescence is not correlated with other characters. It is therefore concluded that $H$. lanceolatum does not occur in Britain and that all plants previously reported as $H$. lanceolatum belong to $H$.

prenanthoides. Pugsley (1948) noted simple hairs occurred on both the peduncles and bracts of $H$. prenanthoides, and rejected the occurrence of $H$. lanceolatum noting plants were typical $H$. prenanthoides; I agree with his interpretation.

Compared to many other Hieracium clones/species, H. prenanthoides in Britain is also quite variable, especially in terms of size, branching and leaf shape and hair clothing. The stems have many simple hairs, particularly below, and casual observation indicates the occurrence of simple hairs in the inflorescence is related to hairiness of the rest of the plants though this has not been formally quantified.

British H. prenanthoides were assumed to be apomictic by Sell \& Murrell (2006) and stated as such, but further experiments are required to verify this properly (e.g. Kocián 2013); the cultivation of two clones from different sites which retained their original characters indicates this is very likely.

Chrtek et al. (2020) note that across its range $H$. prenanthoides consists of a morphologically rather invariant diploid cytotype, and morphologically extraordinarily variable triploid and tetraploid cytotypes most of which are of allopolyploid origin. The British $H$. prenanthoides material analysed morphologically here was found to have slightly longer auricles and broader bracts than European material which may, with further study, merit taxonomic recognition in its own right.

The elimination of $H$. lanceolatum as a British species is yet another example of European or Scandinavian species reported for Britain being rejected when careful comparisons are made (e.g. H. carpathicum Besser, Rich \& Scott, 2011; H. dovrense Fr., Rich, 2011; 12 Scandinavian taxa, Tyler, 2014, McCosh, 2015).

\section{Acknowledgements}

I am grateful to Matthieu Lefebvre, Herbarium curator at the Natural History Museum of Grenoble, for his help with original material from Villars herbarium, and to the Keepers of BM, CGE, E and NMW for access to the collections, to Günter Gottschlich and Patrik Mraz for discussion, to David Price for help with translation and David McCosh for comments on the draft.

\section{References}

Arvet-Touvet, C. 1873. Monographie des Pilosella et des Hieracium du Dauphiné suivie de l'analyse de quelques autres plantes. Grenoble: Prudhomme. Backhouse, J. jun. 1856. A monograph of the British Hieracia. York: William Simpson. 
Chrtek, J. jun., Mráz, P. \& Severa, M. 2004. Chromosome numbers in selected species of Hieracium s. str. (Hieracium subgen. Hieracium) in the Western Carpathians. Preslia, Praha 76: 119-139.

Chrtek, J., Mráz, P., Zahradníček, J., Mateo Sanz, G. \& Szeląg, Z. 2007. Chromosome numbers and DNA ploidy levels of selected species of Hieracium s.str. (Asteraceae). Folia Geobotanica 42: 411-430.

Chrtek, J., Mráz, P., Belyayev, A., Paštová, L., Mrázová, V., Caklová, P., Josefiová, Zagorski, D., Hartmann, M., Jandová, M., Pinc, J., \& Fehrer, J. 2020.

Evolutionary history and genetic diversity of apomictic allopolyploids in Hieracium s.str.: morphological versus genomic features. American Journal of Botany 107: 1-25.

Gottschlich, G. \& Raabe, U. 2011. Hieracium prenanthoides Vill., in Greuter, W. \& Raus, T., Eds. Med-Checklist Notulae, 30. Willdenowia 41: 311-328.

Hammer, Ø., Harper, D. A. T. \& Ryan, P. D. 2001. PAST: Paleontological Statistics Software Package for Education and Data Analysis. Palaeontologia Electronica 4(1): 9pp. http://palaeo-electronica.org/2001 1/past/issue1 01.htm.

Hayirlioğlu-Ayaz, S. \& İnceer, H. 2004. Chromosome numbers of some species of the genus Hieracium s. str. (Asteraceae) from Turkey. Folia Geobotanica 39: 319325.

Hooker, W. J. \& Arnott, G. A. W. 1850. The British flora. $6^{\text {th }}$ ed. London: Longman, Brown, Green \& Longman.

Ilnicki, T. \& Szeląg, Z. 2011. Chromosome numbers in Hieracium and Pilosella (Asteraceae) from Central and South-eastern Europe. Acta Biologica Cracoviensia, Series Botanica 53: 102-110.

Kocián, J. 2013. Reproduction systems of the Hieracium prenanthoides polyploid complex. MSc thesis, Department of Botany, Faculty of Science, Palacky University in Olomouc, $65 \mathrm{pp}$. (in Czech).

Linton, W. R. 1905. An Account of the British Hieracia. London: West Newman \& Co. Májovský, J. (ed.) 1974. Index of chromosome numbers of Slovakian flora (Part 3). Acta Facultatis Rerum Naturalium Universitatis Comenianae series Physiologia plantarum 22: 1-20.

McCosh, D. J. 2015. New names for some British Hieracia (Asteraceae). New Journal of Botany, 5: 119-127. https://doi.org/10.1179/2042349715Y.0000000009

McCosh, D. J. \& Rich, T. C. G. 2018. Atlas of British and Irish Hawkweeds (Pilosella Hill and Hieracium L.). 2nd ed. Harpenden: Botanical Society of Britain and Ireland.

Pugsley, H. W. 1948. A Prodromus of the British Hieracia. Journal of the Linnean Society of London (Botany) 54: 1-356.

Rich, T. C. G. 2011. Hieracium maccoshiana, a new Scottish hawkweed related to $H$. dovrense (section Alpestria, Asteraceae). PhytoKeys 3: 1-8.

Rich, T. C. G. \& Scott, W. 2011. British Northern Hawkweeds. A monograph of British Hieracium section Alpestria. London: Botanical Society of the British Isles.

Sell, P. D. 1987. An introduction to the study of the British Hieracia. 1. History and classification. Watsonia 16: 365-371. http://archive.bsbi.org.uk/Wats16p365.pdf

Sell, P. D. \& Murrell, G. 2006. Flora of Great Britain and Ireland, volume 4. Cambridge: Cambridge University Press. 
Sell, P. D. \& West, C. 1976. Hieracium L., in Tutin et al., eds. Flora Europaea. Volume 4 Plantaginaceae to Compositae (and Rubiaceae). Cambridge: Cambridge University Press.

Stafleu, F. A. \& Cowan, R. S. 1988. Taxonomic literature: a selective guide to botanical publications and collections with dates, commentaries and types. Utrecht: W. Junk.

Tison, J.-M. \& de Foucault, B. (coords.) 2014. Flora Gallica. Flore de France. Mèze: Biotope.

Tyler, T. 2010. Nomenclature of members of Hieracium sect. Alpestria, Foliosa and Prenanthoidea (Asteraceae) reported from Sweden. Nordic Journal of Botany 28: 561-580.

Tyler, T. 2014. Critical notes on species of Hieracium (Asteraceae) reported as common to Sweden and Britain. New Journal of Botany 4: 25-32. https://doi.org/10.1179/2042349713Y.0000000034

Villars, D. 1779. Prospectus de I'Histoire des Plantes de Dauphiné. Grenoble.

Villars, D. 1788. Histoire des Plantes de Dauphiné: Contenant une Préface Historique, un Dictionnaire des Termes de Botanique, les Classes, les Familles, les Genres, \& les Herborisations des Environs de Grenoble, de la Grande Chartreuse, de Briançon, de Gap \& de Montelimar. Paris.

Williams, F. N. 1902. Prodromus florae Britannicae. Brentford: C. Stutter.

Zahn, K. H. 1922. Compositae - Hieracium, in Engler, A. Das Pflanzenreich 77 (IV, 280). Leipzig: von Wilhelm Engelmann.

Copyright retained by author(s). Published by BSBI under the terms of the Creative Commons Attribution 4.0 International Public License.

ISSN: $2632-4970$

https://doi.org/10.33928/bib.2020.02.133 